\title{
New records of several rare spider species (Araneae) from south-eastern Poland
}

\author{
Robert ROZWAŁKA ${ }^{1}$ and Tomasz OLBRYCHT ${ }^{2}$ \\ ${ }^{1}$ Department of Zoology, University of Maria Curie-Skłodowska, Akademicka 19 Str., 20-033 Lublin, Poland; e-mail: \\ arachnologia@wp.pl \\ ${ }^{2}$ Agroecology Team, Faculty of Biology and Agriculture, University of Rzeszów, M. Ćwiklińskiej 1a Str., 35-601 \\ Rzeszów, Poland; e-mail: tkolbr@univ.rzeszow.pl
}

\begin{abstract}
The paper presents new data on seven rare spider species in Poland: Anelosimus vittatus, Clubiona corticalis, Nusoncus nasutus, Pocadicnemis carpatica, Pseudicius encarpatus, Pseudomaro aenigmaticus and Talavera thorelli. Their current locations is presented on maps. Moreover, the figures illustrating the main diagnostic features of Clubiona corticalis, Pseudomaro aenigmaticus and Talavera thorelli are included.
\end{abstract}

Key words: rare spiders, distribution, Pseudomaro aenigmaticus, Talavera thorelli

\section{INTRODUCTION}

More than 800 spider species are reported from Poland (Kupryjanowicz 2008, Rozwałka \& Stańska 2008). This would suggest that the degree of exploration of Polish fauna against Central Europe can be considered as good. However, further studies of various arachnologists constantly enriches our knowledge on the occurrence and distribution of previously known as well as the newly found species in the country (e.g. Rozwałka 2012, Rozwałka et al. 2013, Wiśniewski et al. 2013, Hajdamowicz et al. 2014, Rozwałka 2014, Wiśniewski \& Wesołowska 2015). Nevertheless, despite numerous publications, some Polish regions remain poorly researched. This was reported by Starega in 1983, but the problem is still current. Southeastern Poland belongs to such areas. Despite a number of studies regarding Roztocze (e.g. Starega 1984, 2000, Rozwałka 2004) or the Bieszczady Mountains (Staręga 1971, 1972, 2001, Rozwałka 2010a, 2012, 2014), the area of the Eastern Beskid or Sandomierz Basin were poorly investigated. Every new material from there may contain rare or newly discovered species for spider fauna of Poland.

The materials used for this publication were collected by the authors as part of various researches conducted in southern Poland or were delivered by a number of collaborators and colleagues. Moreover, the authors used the materials collected near Pacław within the framework of the project number: DEC-2013/11/B/NZ9/00793 financed by the National Centre of Science.

In this study the authors present data on the newly recorded sites of some spider species rarely reported from Poland, mainly from south-eastern part of the country.

\section{REVIEW OF SPECIES}

\section{Anelosimus vittatus (C. L. Koch, 1836)}

West Palearctic species, relatively frequent in Europe, but so far in Poland it has been reported from scattered and not numerous locations (Fig. 1). The reason why the distribution of this species was not studied in detail, could be its specific habitat. Adult individuals of 
A. vittatus live among leaves and branches high in tree crowns and, as a result of that, they are infrequently caught (Dziabaszewski 1976, Le Peru 2011, observations by R. Rozwałka). The young ones climb down to the ground to the lower trunk sections and winter in crevices or under the bark of trees, in the summer with the appearance of new leaves, they return to tree crowns (observation by R. Rozwałka).

Literature data from Poland: Menge 1868, Lebert 1875, Fickert 1876, Kulczyński 1876, Kulczyński 1881, Pax 1936, Petrusewicz 1937, Dziabaszewski 1961a, b, 1965, Czajka 1966, Prószyński \& Staręga 1971, Dziabaszewski 1976, Staręga 1983, Woźny et al. 1988, Dziabaszewski 1991, Czajka \& Domin 1993, Szymkowiak 1993, Otto \& Floren 2007, Rozwałka \& Bielak-Bielecki 2008, Stańska \& Łydkowska 2008, Rozwałka 2014.

New data:

Bolestraszyce [FA 32], arboretum, on chestnut tree, 5 Jun 2015 - 1ठ, leg. R. Rozwałka;

Chrystkowo [CE 21], orchard, Moericke trap in the crowns of trees, 4-13 May 2016-1今, leg.

E. Motyka \& G. Czapran;

Czudec [EA 63], former manor park, under platanus bark; 13 Jun 2014 - 1q, 1 juv., leg. K.

Ochał \& K. Basamania;

Dubiecko [FA 02], former manor park, under platanus bark, 6 Mar 2014 - 6 juv. leg. G. Żółty;

Kraków [DA 24], botanical garden, on brick wall, 31 May 2015 - 19, leg. R. Rozwałka;

Lublin-Centrum [FB 07], chestnut tree, sticky traps on bark, 30 May 2005 - 2 juv., leg. R.

Rozwałka;

Lublin-Sławin (Botanical Garden) [FB 08], chestnut tree, sticky traps on bark, 30 May 2005 1 juv. leg. R. Rozwałka;

Lublin-Zemborzyce [FB 07], chestnut tree, sticky traps on bark, 18 May 2005 - 1 sub $\widehat{\jmath}, 1$ juv., leg. R. Rozwałka;

Łańcut [EA 84], castle park, under platanus bark, 6 Mar 2014 - 4 juv., leg. S. Burek, B. Cieśla \& N. Cisek;

Łopuszka Mała [FA 03], former manor park, under platanus bark, 13 Mar 2014 - 4 juv., leg. B. Cieśla;

Medyka [FA 31], former manor park, under platanus bark, 13 Apr $2014-2 q \circ, 15$ juv., leg. T. Olbrycht;

Nisko [EA 89], park near hospital, under platanus bark, 23 Mar 2014 - 2 juv., leg. M. Kiljańska;

Przemyśl [FA 21], castle park, under platanus bark, 2 Apr 2015 - 1 juv., leg. T. Olbrycht; the site reported by Prószyński and Staręga (1971) on the basis on unpublished data of W. Kulczyński;

Przeworsk [FA 04], palace park, under platanus bark, 9 Mar 2014 - 3 juv., leg. T. Olbrycht;

Rafa [CD 19], orchard, Moericke trap in the crowns of trees, 2-25 May $2016-1{ }^{\lambda}$, leg. J. Pająkowski;

Roźwienica [FA 13], former manor park, under platanus bark, 12 Apr 2014 - 1 juv., leg. A. Kłopot;

Rzeszów-Miłocin [EA 74], former manor park, under platanus bark, 11 Mar 2014 - 1 juv., leg. A. Polak;

Rzeszów-Solidarity Park [EA 74], city park, under platanus bark, 9 Mar 2014 - 14 juv., leg. E. Kościółek;

Rzeszów-Zalesie [EA 74], former manor park, under platanus bark, 1 Mar 2014 - 3 juv., leg. T. Olbrycht;

Rzeszów-Słocina [EA 74], former manor park, under platanus bark, 2 Mar 2014 - 4 juv., leg. T. Olbrycht; 
Sartowice Dolne [CE 32], orchard, Moericke trap in the crowns of trees, 8-21 May $2016-1 \widehat{\partial}$, leg. J. Pająkowski;

Świerże [FB 97], former manor park, in hollow tree or on bark, 4 Apr $2002-1$ juv., 11 Oct 2002 - 7 juv., leg. R. Rozwałka,

Urzejowice [FA 04], former manor park, under platanus bark, 14 Dec 2014 - 4 juv., leg. T. Olbrycht;

Wola Sękowa [EV 78], former manor park, under platanus bark, 21 Mar 2014 - 4 juv., leg. A.

Sołtysik;

Zaczernie [EA 74], former manor park, under platanus bark, 11 Mar 2014 - 4 juv., leg. A. Polak; Zarzecze [FA 13], former manor park, under platanus bark, 16 Mar 2014 - 2 juv., leg. A. Kłopot; Zawada [EA 03], former manor park, under platanus bark, 20 Mar 2014 - 1 , 3 juv., leg. M. Więcek.

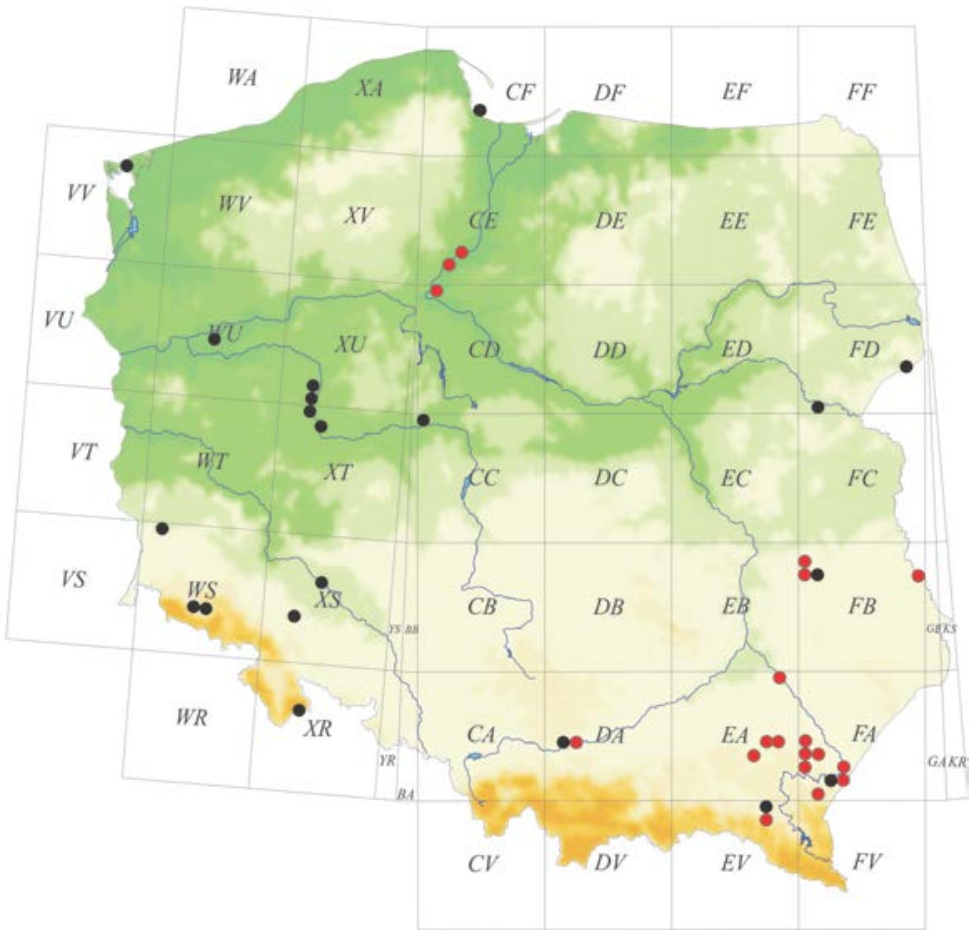

Fig. 1. Distribution of Anelosimus vittatus in Poland; literature data (black dots) and new records (red dots).

Remarks: Another species of the genus Anelosimus Simon, 1891, i.e. A. pulchellus (Walckenaer, 1802) was also noted in Poland. However, Prószyński \& Staręga (1971) in their Catalogue, recognized that the data from the 19th century publications on Anelosimus pulchellus from Polish area refer to A. vittatus. Still, A. pulchellus was noted also in the later papers (by Baran 1933, Dziabaszewski 1961 and by Stańska \& Łydkowska 2008) which were the basis for including A. pulchellus in various lists of spiders of Poland (Petrusewicz 1937, Prószyński \& Staręga 1971, Staręga 1983, Prószyński \& Staręga 1997, Kupryjanowicz 2008, Rozwałka \& Stańska 2008) and of Europe (e.g. Blick et al. 2004, Le Peru 2011, Arachnologische Gesellschaft 2017, Nentwig et al. 2017).

Bearing in mind, however, that identification of a number of different species mentioned by Baran (1933) have been questioned by later authors (see e.g. Prószyński \& Staręga 1971, 
Staręga 1983, Rozwałka 2014), it seems most likely, that the data on A. pulchellus should be relevant to $A$. vittatus, which was not mentioned in the publication. Farther, Dziabaszewski (1961b) reported $A$. pulchellus on the basis of a juvenile individual, whereas Stańska and Łydkowska (2008) had at their disposal also only juvenile specimens coexisting with $A$. vittatus. Because of the high morphological similarity of both species and high individual variability of $A$. vittatus (Roberts 1995, Le Peru 2011, Nentwig et al. 2017), the above records should be considered as doubtful. Therefore, there is a lack of reliable information regarding the occurrence of $A$. pulchellus in Poland and until a credible material is disclosed, the species should be removed from the list of spiders of Poland.

\section{Clubiona corticalis (Walckenaer, 1802)}

European-West Siberian species, quite frequent according to Nentwig et al. (2017), but most likely this remark refers to Western Europe. In Poland (Fig. 2) and in the Czech Republic (Buchar \& Růžička 2002) as well as in Slovakia (Gajdoš et al. 1999) C. corticalis (Fig. 7a-e) is a rare species known from not many sites. This is a spider species living in tree hollows and bark full of gaps and cracks of numerous tree species, usually conifer, sometimes also rock crevices and spaces under rocks (Staręga 1988, Nentwig et al. 2017).

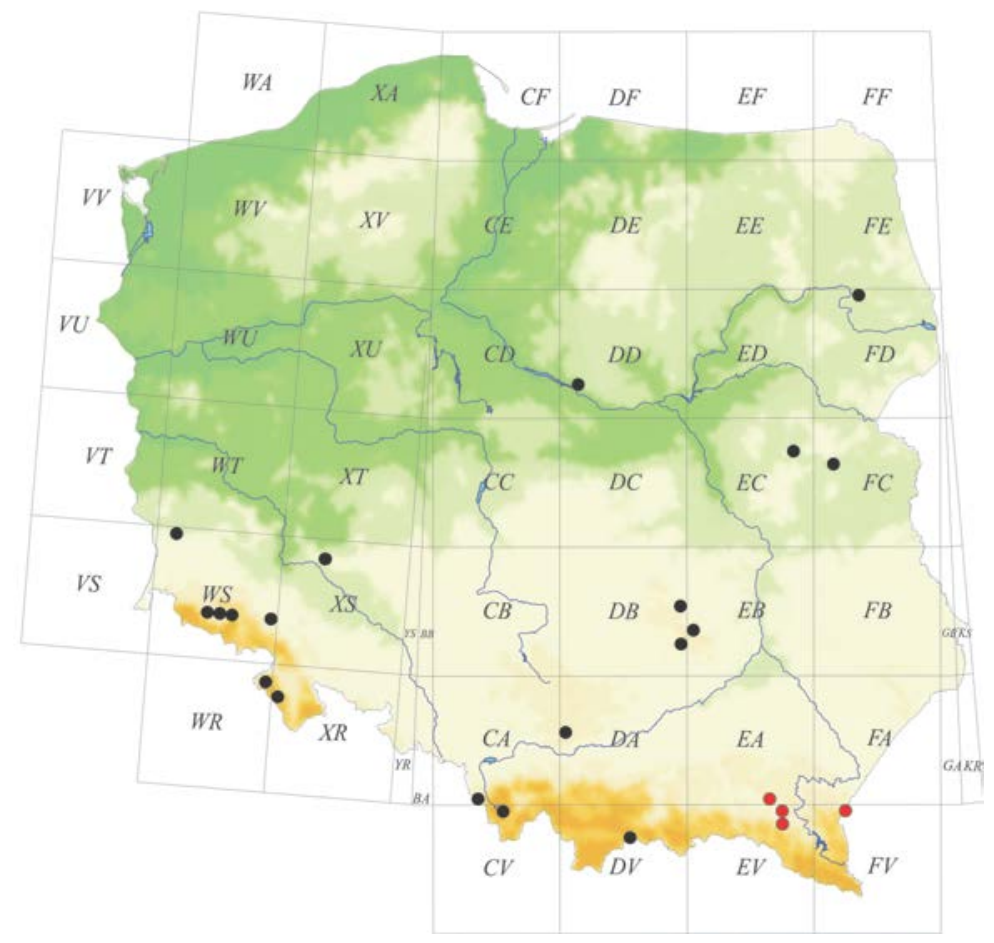

Fig. 2. Distribution of Clubiona corticalis in Poland; literature data (black dots) and new records (red dots).

Literature data from Poland: Kulczyński 1881, 1882, Bösenberg 1902, Dahl 1902, Petrusewicz 1937, Pilawski 1967, Prószyński \& Staręga 1971, Staręga 1976, 1978, 1983, 1984, Staręga \& Nakaziuk 1987, Staręga 1988, Woźny et al. 1988, Czajka \& Domin 1993, Chyży \& Starega 1997, Staręga 2003. 

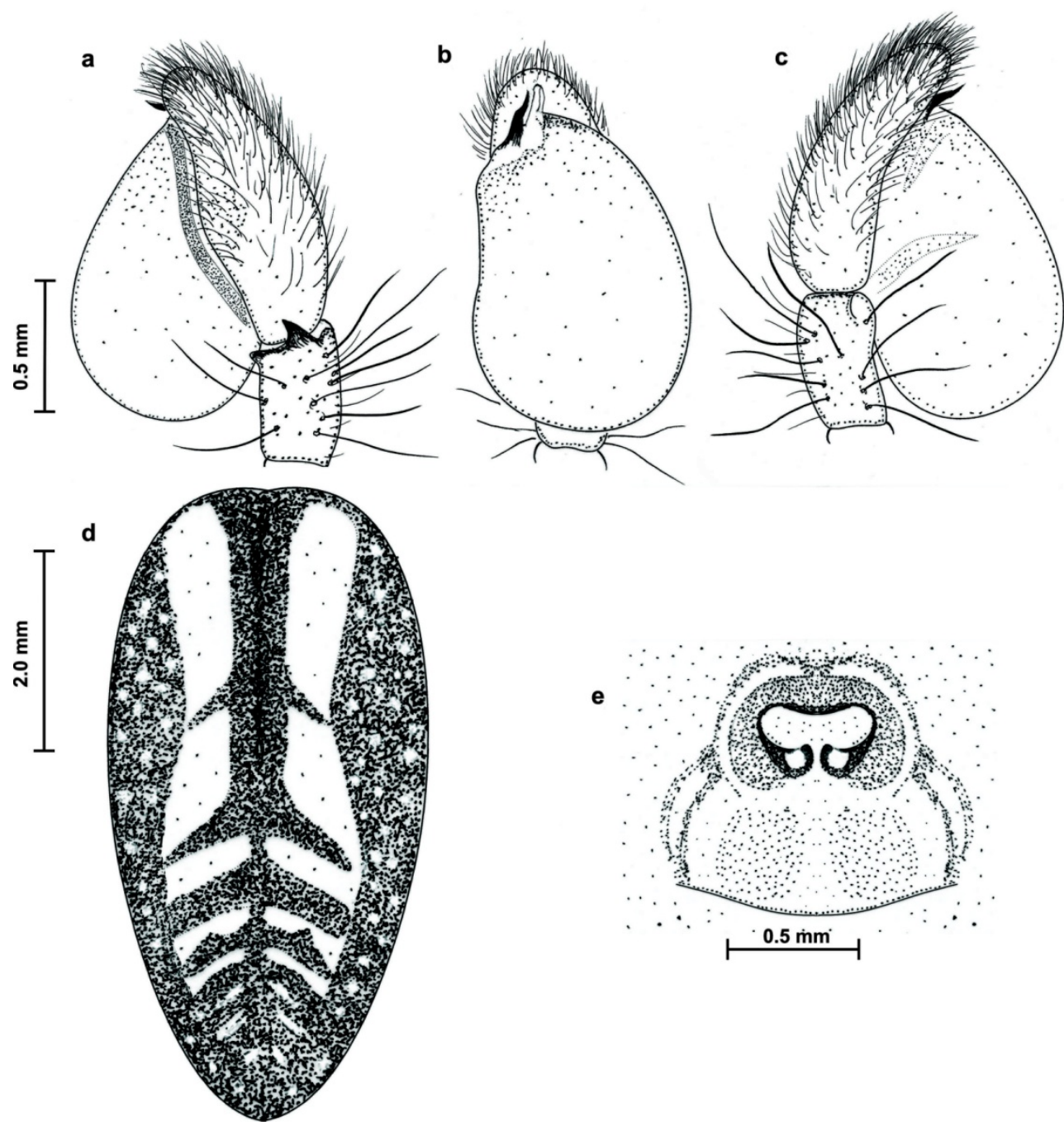

Fig. 3. Clubiona corticalis: lateral (a), frontal (b) and medial (c) view of male palp, female abdomen, dorsal view (d) and female epigynum (e).

New data:

Wola Sękowa [EV 78], former manor park, under platanus bark, 21 March $2014-1$, leg. A. Sołtysik;

Posada Zarszyńska [EV 79], former manor park, hollow in pedunculate oak, 31 Dec 2013 2 juv., leg. T. Olbrycht;

Kombornia [EA 60], former manor park, under platanus bark, 22 Mar 2014 - 2 juv., leg. T. Olbrycht; Pacław [FV 29], old solitary pedunculate oak in forest outskirts, IBL-5 pitfall trap, 05 Jun21 Jun 2015 - 1ð, leg. T. Olbrycht;

Świętokrzyski Park Narodowy [EB 03], protection area "Święty Krzyż", forest section 113g, fir forest, Netocia type trap, 15 Oct-15 Nov 2012 - 19, leg. personnel of Świętokrzyski National Park; [The site noted by Staręga (1988)]. 
Remarks: According to Bösenberg (1902), Petrusewicz (1937), Reimoser (1937), Prószyński and Staręga (1971) as well as Staręga (1983), the sites of C. corticalis known from Menge's work (1873) referred to C. subsultans. Each of these authors assumed that the specimens collected in Gdańsk-Orunia and in Kartuzy (Menge 1873: p. 372-373, fig. 212a-c) described by Menge as $C$. corticalis actually belonged to $C$. subsultans females. The drawings illustrating the male specimen (Menge 1873: fig. 212h-j) are not sufficiently precise to identify which species was presented. In our opinion, it is not definitely the male specimen of $C$. corticalis as it was assumed by Prószyński and Staręga (1971), neither is it a male of $C$. subsultans. Moreover, due to the lack of material from East Prussia at that time, Menge used for the description a male specimen made available to him by Thorell [from Sweden?], which was clearly highlited in the text (Menge 1873: p. 373). Hence, the assumption made by Prószyński and Staręga (1971) that the Menge's description (1873) of the male concerns only C. corticalis and Polish locations of this species could have been a double fault.

\section{Nusoncus nasutus (Schenkel, 1925)}

Very rare boreomontane species living in mosses and litter of spruce and fir forests, it can be also encountered in other habitats where the subgrade is covered with a thick layer of moss (Nentwig et al. 2017). Komposch and Natmessnig (2001) described an example of mass occurrence of this species and its flying on cob webs. In Poland $N$. nasutus was reported from not many locations scattered in southern and eastern part of the country (Fig. 4).

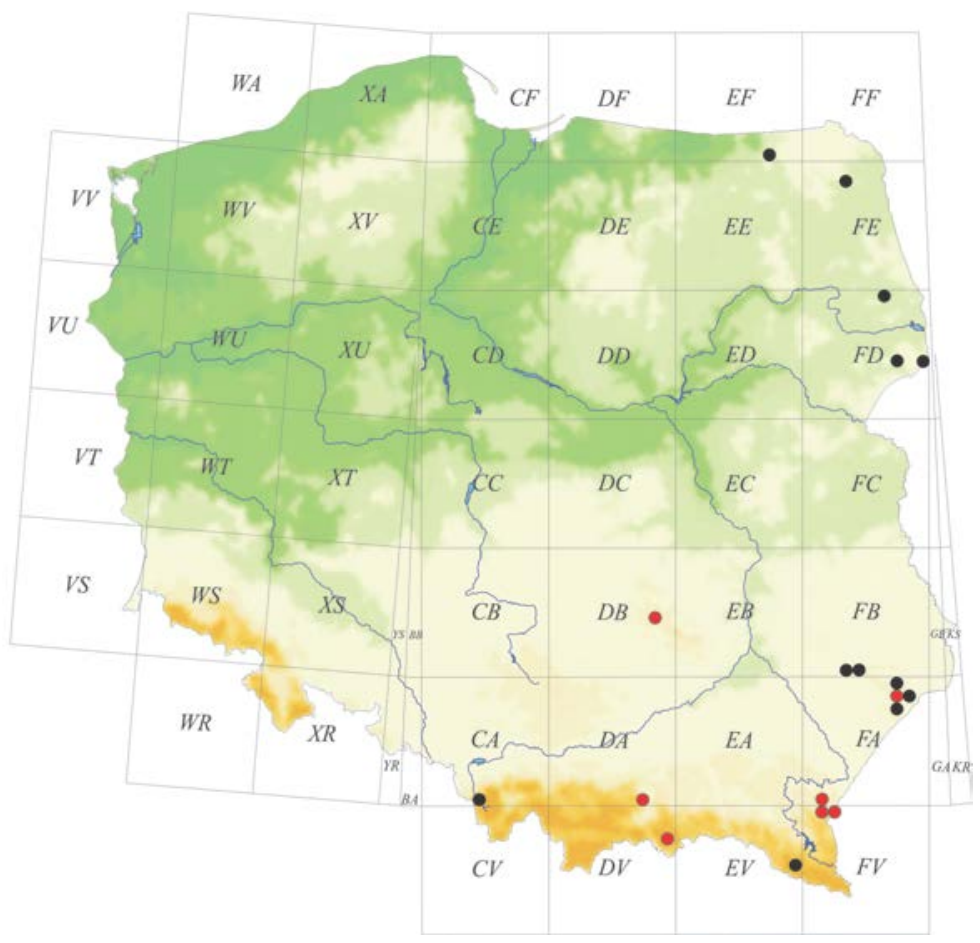

Fig. 4. Distribution of Nusoncus nasutus in Poland; literature data (black dots) and new records (red dots).

Literature data from Poland: Starega 1972, 1974, 1983, 1996a, 2000, Lęgowski 2001, Staręga 2001, Staręga \& Kupryjanowicz 2001, Staręga 2003, Rozwałka 2004. 
New data:

Massif of Cień Mount near Arłamów [FV19], beech forest, Netocia type trap, 25 May 2015 1 , , leg. A. Melke;

Pacław [FV 29], mixed forest, Barber pitfall trap, 23 May 2015 - 19, leg. T. Olbrycht;

Kopciowa [DV 97], Moericke trap on snow, 23 Mar 2011 - 1q, 17 Mar-18 Apr $2012-2 \hat{\widehat{\partial}} \widehat{\text {, }}$ 2 우, leg. M. Łuszczak;

Bełżec [FA 78], approx. 60 year-old pine forest, anthropogenic in origin, pitfall traps, 25 March-15 Apr 2006 - 1 , leg. R. Rozwałka; approx. 40 year-old pine forest, anthropogenic in origin, pitfall trap, 15 June-1 May 2006 - 19; leg. R. Rozwałka;

Świętokrzyski National Park [DB 84], protected area "Klonów", forest section 239i, bark beetle trap, 15 Mar-15 Apr 2011 - 19; leg. L. Buchholz et al.;

Białowodzka Góra Mt. [DA 70], beech forest, forest litter sieving, 2 May 2007 - 1q, leg. R. Rozwałka;

Kopysno [FA 10], blackthorn bushes, plant litter and moss sieving, 23 May 2015 - 1일. leg. R. Rozwałka.

\section{Pocadicnemis carpatica (Chyzer, 1894)}

Very rare Alpine-Carpathian species connected with lower mountain locations, reaching in Poland the northern border of its range (Fig. 5). It lives in mossy greensward of fairly clear forest and undergrowth habitats, sometimes also mountain meadows and clearings (Rozwałka 2008, 2012, Nentwig et al. 2017).

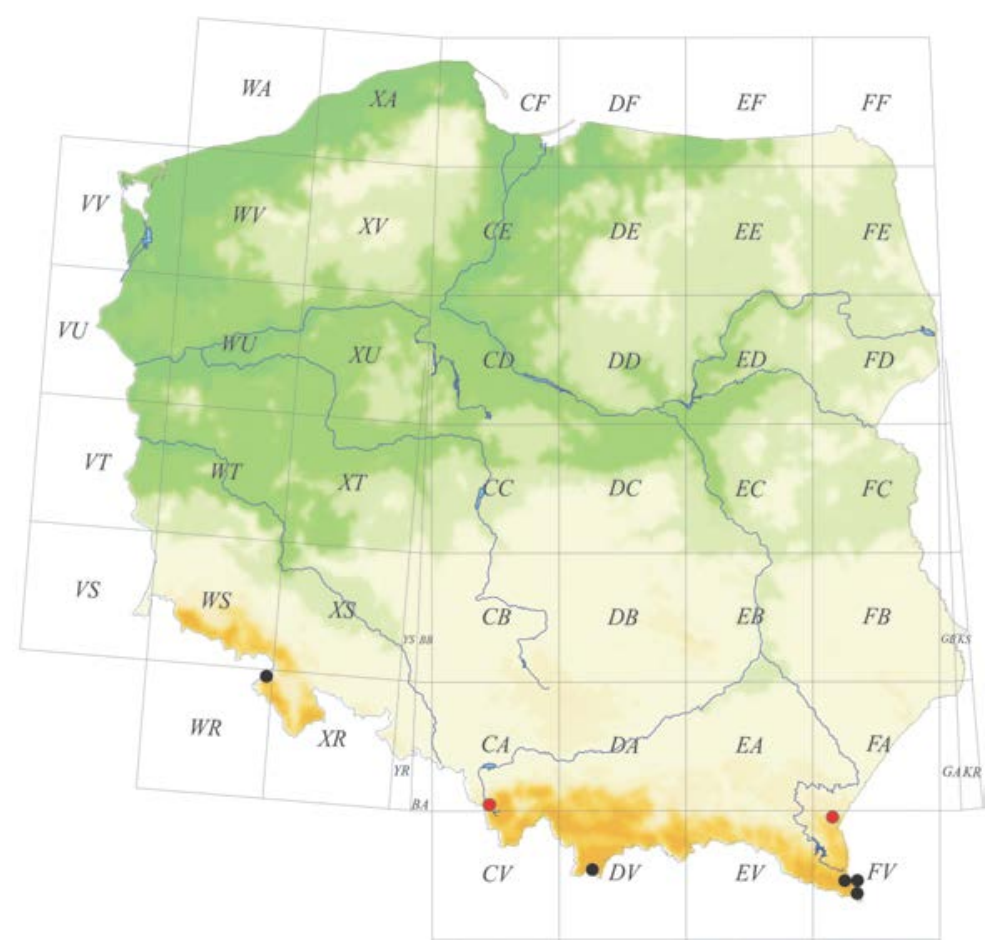

Fig. 5. Distribution of Pocadicnemis carpatica in Poland; literature data (black dots) and new records (red dots). 
Literature data from Poland: Rozwałka 2008, 2010a, 2012.

New data:

Mała Czantoria Massif [CA 40], sycamore-beech forest, in litter and under stones, 8 Jun 1967 -

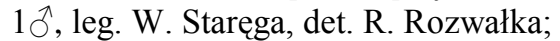

Massif of Dział Mountain between Jamna Górna and Arłamów [FV 19], sycamore-beech wood forest, barrier trap, 23 May $2015-1 \hat{\jmath}$, leg. A. Melke.

\section{Pseudicius encarpatus (Walckenaer, 1802)}

Rare species in Europe, living in bark gaps of various tree species in cleared forest biotopes, parks and gardens. Sometimes collected on walls and fences (Żabka 1997, Rozwałka \& Bielak-Bielecki 2008, Nentwig et al. 2017), and according to Almquist (2006) also under stones at sea coasts. It builds primitive webs to catch prey, which makes it distinct from domestic representatives of Salticidae (Dobroruka 1995, Żabka 1997). In Poland this spider species is rarely reported, known from scattered sites (Fig. 6).

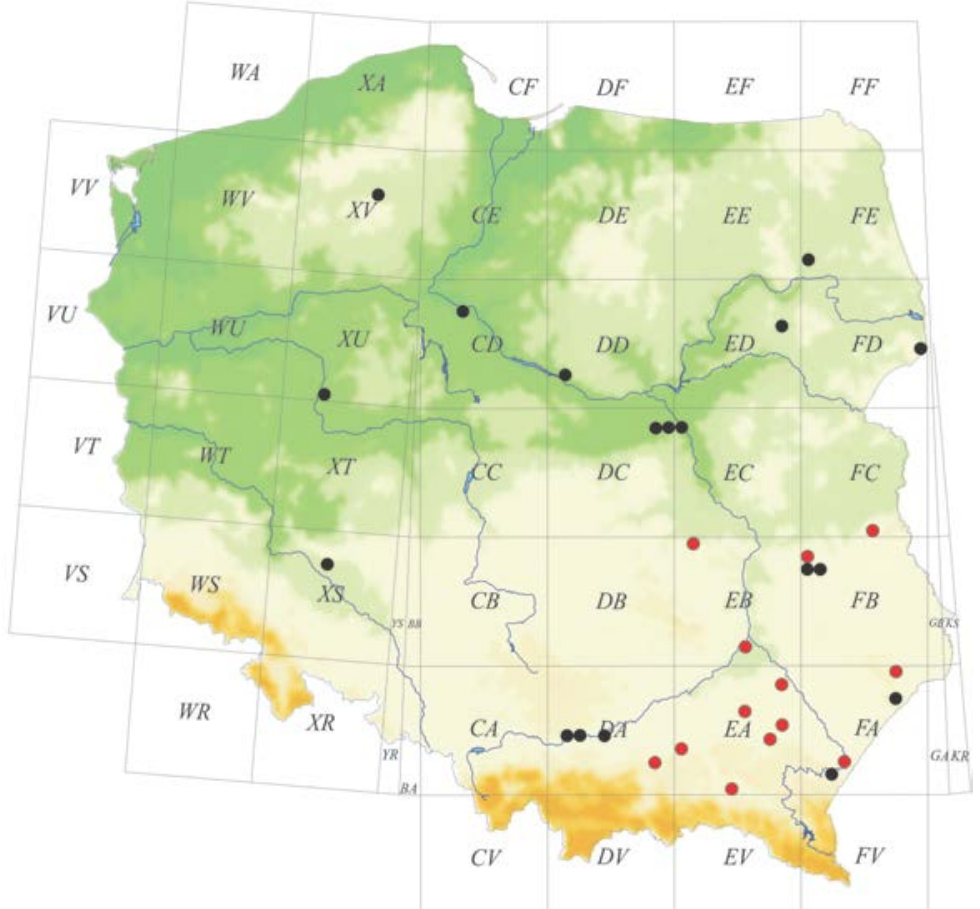

Fig. 6. Distribution of Pseudicius encarpatus in Poland; literature data (black dots) and new records (red dots).

Literature data from Poland: Taczanowski 1866, Kulczyński 1876, 1881 1884, 1890 Petrusewicz 1937, Pilawski 1963, Prószyński \& Staręga 1971, Staręga 1974, Krzyżanowska et al. 1981, Staręga 1983, 1984, Dziabaszewski 1989, Sterzyńska \& Slepowroński 1994, Żabka 1997, Starega \& Kupryjanowicz 2001, Kupryjanowicz 2005, Stańska 2007, Rozwałka \& Bielak-Bielecki 2008.

New records:

Biała Góra [FA 79], xerothermic grassland with isolated young pines, sweeping, 6 Jun 1997 $1{ }^{\lambda}$, leg. R. Rozwałka; 
Bolestraszyce [FA 32], arboretum, on chestnut trunk, 2 May 2014 - 1 juv.; 5 Jun 2015 - 1§^; leg. R. Rozwałka;

Charzewice [DA 82], former manor park, under platanus bark, 23 Mar 2014 - 2 juv., leg. M. Zeman; Dąbrówki [EA 85], former manor park, under platanus bark, 10 Apr 2014 - 19, leg. B. Cieśla; Lublin-Sławin (Botanical Garden) [FB 08], chestnut bark, sticky traps; 30 May 2005 - 2 juv., leg. R. Rozwałka;

Pieszowola (Poleski National Park) [FC 50], forest outskirts, on bark of an old oak, May 1995 $-1 \hat{\jmath}$, leg. R. Rozwałka;

Góry Pieprzowe Nature Reserve [EB 51], xerothermic bushes, pitfall traps, 1 Jun-14 Jun 2008 $-1 \widehat{\jmath}$, leg. S. Łysiak;

Rudnik [EA 88], young growth, Moericke trap, 14 May-8 Jun 1998 - 1 juv., leg. T. Huflejt \& M. Kędzia;

Rzeszów-Solidarity Park [EA 74], under platanus bark, 9 Mar 2014 - 1 juv., leg. E. Kościółek; Tarnów [EA 03], municipal park, under platanus bark, 20 Mar $2014-1$ \%, leg. M. Dychtoń \& M. Szwabowski;

Werynia [EA 56], former manor park, under platanus bark, 10 Mar 2014 - 1 juv., leg. M. Tanona;

Żarnowiec [EA 40], former manor park, under platanus bark, 8 Mar 2014 - 1 juv., leg. M. Wójcik.

Remarks: Figure 6 does not show the data presented by Mikulska (1950) on the occurrence of Pseudicius encarpatus in the litter of spruce and beech-fir forest on Barania Mountain Massif, where the species was registered as almost only and relatively abundant (10 specimens) jumping spider. These and other details of the collection (Rozwałka 2010b) allow us to recognize that this was a misidentification.

\section{Pseudomaro aenigmaticus Denis, 1966}

Very rare species living underground (Nentwig et al. 2017). Known from few sites in: Great Britain, Belgium, Luxembourg, Germany, Poland, the Czech Republic, Austria, Switzerland and Italy (Nentwig et al. 2017). Caught in caves (Denis 1966, Brignioli 1971, Thaler \& Plachter 1983, Staudt et al. 2012) or in various open habitats (Snazell 1978, Roberts 1987, Staręga 1996b, Nentwig et al. 2017), where it presumably occupies the burrows of small mammals. In Poland this species is known from only three sites located on post-mining dumps in Silesia (Starega 1996b) (Fig. 7). Presented site in Pacław as is the farthest east reaching within established range of this species.

Literature data from Poland: Staręa 1996b.

New data:

Pacław [FV 29], oak and fir forest, IBL-5 barrier trap, 1 Sept-13 Sept 2015 - 1일. leg. T. Olbrycht;

Remarks: Pseudomaro aenigmaticus is also reported from China (Fei \& Gao 1996, WSC 2017) but undoubtedly it is the result of misidentification. According to the description by Fei and Gao (1996) the length of the specimen from China is $2.24 \mathrm{~mm}$, which is the value significantly different from the values reported for $P$. aenigmaticus $-1.50-1.70 \mathrm{~mm}$ (Denis 1966, Brignioli 1971 (1.2 mm!), Snazell 1978, Thaler \& Plachter 1983, Nentwig et al. 2017. Length of specimen from Pacław is $1.33 \mathrm{~mm}$. Moreover, the copulatory canals pattern and the shape of seminal receptacles (Fei \& Gao 1996: figs. C-E) differ from that occurring in P. aenigmaticus (compare Denis 1966: fig. 6; Brignoli 1971: figs. 37-39; Saaristo 1971: figs. 4-6; Snazell 1978: 2-5; Brignoli 1979: figs. 68-69; Thaler \& Platcher 1983: figs. 1-2; Thaler 1991: fig. 7; as well as Fig. 8). 


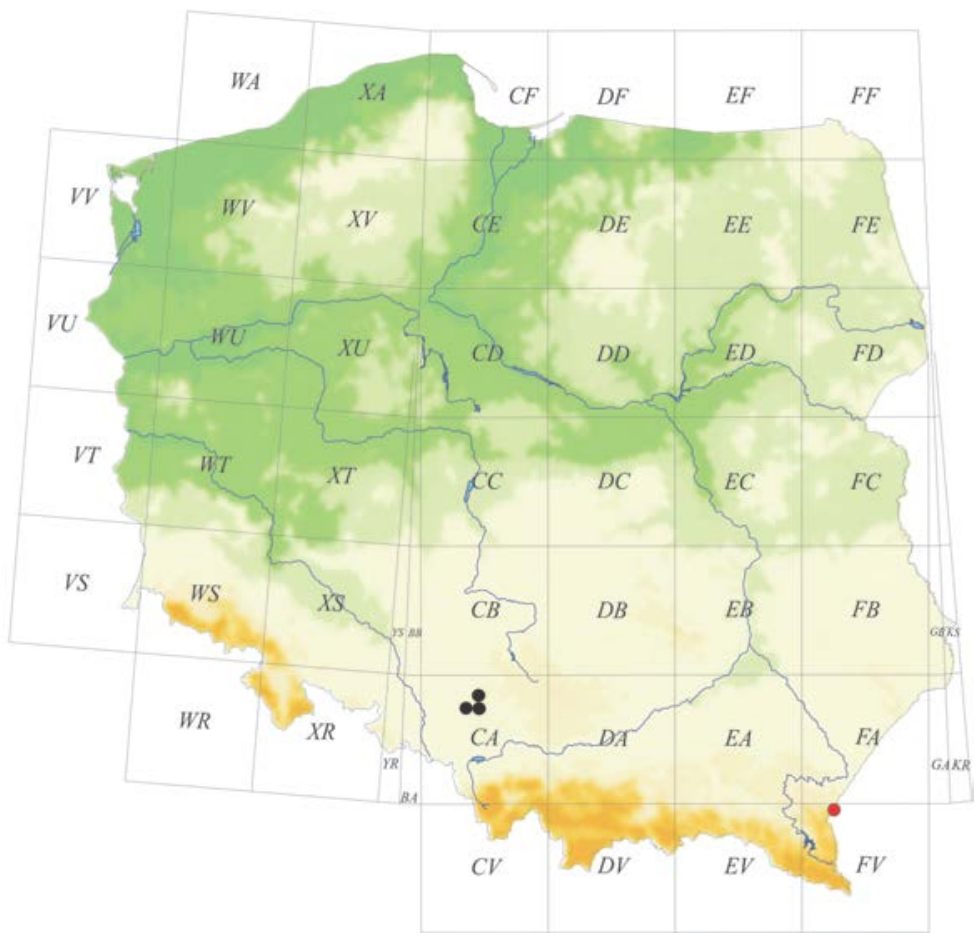

Fig. 7. Distribution of Pseudomaro aenigmaticus in Poland; literature data (black dots) and new records (red dot).

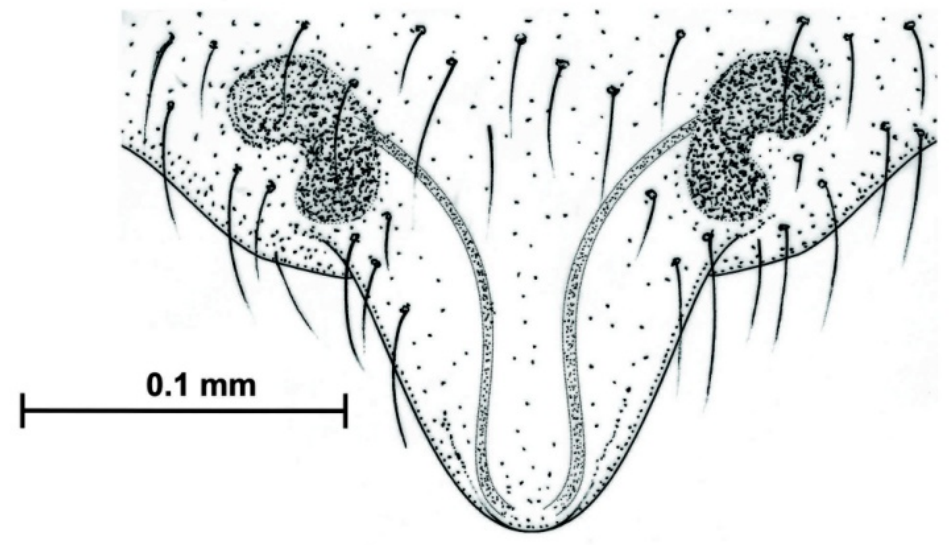

Fig. 8. Female epigynum of Pseudomaro aenigmaticus. 


\section{Talavera thorelli (Kulczyński, 1891)}

Rare European-Siberian species reaching in the east Central Mongolia, often mistaken for other closely related species (Logunov \& Kronestedt 2003). In Poland known only from the area of Zabierzów [DA 15], on the basis of unpublished materials of W. Kulczyński (Prószyński \& Staręga 1971, Żabka 1997). It lives in various grassy and stony, open, sunlit habitats situated most often in the mountain and foothill area. It was also reported from clear pine forests and birch forests, dry meadows etc. (Chvátalová \& Buchar 2002, Almquist 2006, Logunov \& Kronestedt 2003). Figures 9a-b illustrate a male copulatory palp of T. thorelli.
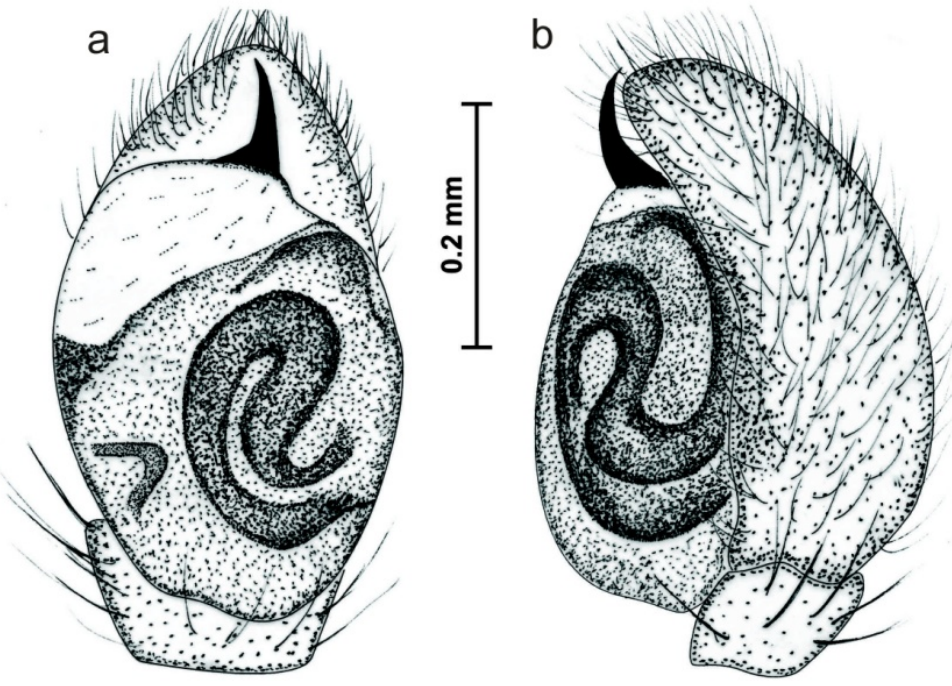

Fig. 9. Talavera thorelli: frontal (a) and lateral (b) view of the male palp.

Literature data from Poland: Prószyński \& Staręga 1971, Staręga 1983, Żabka 1997.

New data:

Dział Mountain Massif, western slope of Kiczora Mts. [FV 19], Netocia type trap installed next to beech scrap, 25 May-16 Jun 2015 - 1ठ̂, leg. A. Melke;

Notes: Żabka (1997: p. 106) wrongly indicates the area of Kraków as locus typicus for T. thorelli. Kulczyński clearly points out that the only specimens he had was an adult female and subadult male collected in Sátoraljaújhely in Hungary (Chyzer \& Kulczyński 1891: p. 44).

\section{DISCUSSION AND CONCLUSIONS}

New data presented in this paper, on the following rare spider species: Anelosimus vittatus, Clubiona corticalis, Nusoncus nasutus, Pocadicnemis carpatica, Pseudicius encarpatus, Pseudomaro aenigmaticus and Talavera thorelli enrich our knowledge on their occurrence and distribution in Poland.

Anelosimus vittatus, Clubiona corticalis and Pseudicius encarpatus belong to species related to tree bark and all are fairly rare. Rare statements of Anelosimus vittatus may be due to the fact that this species spends most of its life in the crowns of trees and it is therefore rarely caught. It should be noted that a number of the reported locations of this species are in urban parks and former manor parks. Such parks are a habitat of numerous rare invertebrate 
connected with old tree stands. Even such as the ones referred to as the "relics of primary forests" (e.g. Jałoszyński \& Konwerski 2001, Bunalski 2012, Czerniakowski \& Olbrycht 2014). The parks are also a habitat of a number of rare spider species which require trees with thick bark, with cracks and gaps.

The data presented for Nusoncus nasutus and Pocadicnemis carpatica is consistent with the assumption that these two species are aeronautic spiders, because they are cought into various traps suspended above the ground level.

The above survey confirmed the occurrence of Talavera thorelli in the Eastern Beskids. This very rare species, a representative of the Salticidae family was reported in Poland only on the basis of W. Kulczyński's notes from Zabierzów area (Prószyński \& Staręga 1971). Therefore, we confirmed the presence of $T$. thorelli only after 100 years since this species was reported in Poland. The presence of other rare species has been confirmed in our research after more a century, as in case of $A$. vittatus from Przemyśl or after several decades as with $C$. corticalis from Święty Krzyż Mountain.

Moreover, we have described and corrected some misleading information that was fixed in the literature for several species. The analysis of the source publications demonstrated that all information on the occurrence in Poland of Anelosimus pulchellus was doubtful. In fact, there is no credible evidence for the presence of this very rare South European species in Poland and the alleged locations of A. pulchellus (Baran 1933, Prószyński \& Starega 1971, Dziabaszewski 1961b, Stańska \& Lydkowska 2008), referred to A. vittatus. We also pointed out the unreliability of other data, i.e. referring the occurrence of Clubiona corticalis in northern Poland, which was based only on Menge's work (1873), and the occurrence of Pseudicius encarpatus in Cieszyn area (Mikulska 1950). In addition, we have also shown that Pseudomaro aenigmaticus can no longer be considered as occurring in China, because the description and the graphic documentation in the study by Fei and Gao (1996) had so large discrepancies that they could not refer to this species.

\section{ACKNOWLEDGEMENTS}

The authors would like to offer very warm thanks to all the people mentioned in the text who provided support while collecting the material or made available the specimens and information used in this study.

\section{REFERENCES}

AlmQUist S. 2006. Swedish Araneae, part 2 - families Dictynidae to Salticidae. Entomologica Scandinavica, Supplement 63: 287-603.

Arachnologische Gesellschaft 2017. Atlas of the European Arachnids. Version 1.18. Available at http://atlas.arages.de, accessed on: 1 May 2017.

BARAN S. 1933. Materjały do fauny pająków (Araneida) okolic Rzeszowa. Sprawozdania Komisyi Fizyograficznej, Kraków, 67: 23-36.

Blick T., Bosmans R., Buchar J., Gajdoš P., Hänggi A., VAn Helsdingen P., RužICKa V., StaręGa W. \& THALER K. 2004. Checkliste der Spinnen Mitteleuropas. Checklist of the spiders of Central Europe. (Arachnida: Araneae). Version 1. Dezember 2004: http://www.arages.de/checklist.html\#2004_Araneae.

BÖSENBERG W. 1902. Die Spinnen Deutschlands. II-IV. Zoologica (Stuttgart), 14: 97-384.

BRIGNOLI P. M. 1971. Note su ragni cavernicoli italiani (Araneae). Fragmenta Entomologica, 7: 121-229.

BRIGNOLI P. M. 1979. Ragni d'Italia XXXI. Specie cavernicole nuove o interessanti (Araneae). Quaderni del Museo di Speleologia, 5 (10): 1-48.

BuCHAR J. \& RŮŽIČKA V. 2002. Catalogue of spiders of the Czech Republic. Peres, Praha, 351 pp.

BUNALSKI M. (ed.) 2012. Chronione chrząszcze dendrofilne zachodniej Polski. Zagrożenia - ochrona - kompensacja. Regionalna Dyrekcja Ochrony Środowiska, Poznań, 200 pp.

ChVÁtAlová I. \& BuCHAR J. 2002. Distribution and habitat of Talavera aperta, T. milleri and T. thorelli in the Czech Republic (Araneae: Salticidae). Acta Societatis Zoologicae Bohemicae 66: 3-11.

CHYZER C. \& KULCZYŃSKI W. 1891. Araneae Hungariae. Budapest, 1: 1-170. 
ChYŻy I. \& StARĘGA W. 1997. Pająki (Araneae) rezerwatu Antoniuk. Parki Narodowe i Rezerwaty Przyrody 16 (1): 27-39.

CzAJKa M. 1966. Pająki (Araneae) Masywu Ślęży. Acta Universitatis Wratislaviensis, Prace Zoologiczne. Wrocław, 2 : 71-124.

CzaJKa M. \& Domin L. 1993. Pająki (Aranei) okolic Ruszowa w Borach Dolnośląskich. Opolskie Towarzystwo Przyjaciół Nauk, Zeszyty Przyrodnicze, Opole, 29: 7-30.

CZERNIAKOWSKI Z. W. \& OlBRYCHT T. 2014. Historic Rzeszów parks as a mainstay of precious invertebrates. Czasopismo Techniczne, Architektura. Politechnika Krakowska, Kraków 111 (6-A): 149-156.

DAHL F. 1902. Über Stufenfänge echter Spinnen im Riesengebirge. Sitzungsberichte der Gesellschaft Naturforschender Freunde zu Berlin, 185-203.

DeNIS J. 1966. Pseudomaro aenigmaticus n. gen., n. sp., araignée nouvelle pour la faune de Belgiue, et un congénère probable de Sibérie. Bulletin de l'Institut Royal des Sciences Naturelles de Belgique, 42 (9): 1-7.

DOBRORUKA L.J. 1995. Utilization of silk, use of webs, and predatory behaviour of the jumping spider Pseudicius encarpatus (Araneida: Salticidae). Acta Societatis Zoologicae Bohemicae, 59: 141-144.

DZIABAsZEWSKI A. 1961a. Z badań nad pająkami Wolińskiego Parku Narodowego i okolicy. Przyroda Polski Zachodniej, Poznań, 4: 210-212.

DziabaszewSKi A. 1961b. Pająki z rodziny Theridiidae Wielkopolskiego Parku Narodowego. Prace Monograficzne nad Przyrodą Wielkopolskiego Parku Narodowego pod Poznaniem, Poznań, 3: 45 pp.

DZIABASZEWSKI A. 1965. Pająki wyspy Wolina ze szczególnym uwzględnieniem Wolińskiego Parku Narodowego. Część I. Prace komisji biologicznej, PTPN, Poznań, 31: 33-131.

DZIABASZEWSKI A. 1976. Studium ekologiczno-faunistyczne nad pajęczakami (Aranae, Opiliones, Pseudoscorpionidea) koron drzew. Seria Zoologia, 4. Poznań, 218 pp.

DZIABASZEWSKI A. 1989. Uwagi faunistyczne o rzadszych gatunkach pająków (Aranei) z Poznania (z listą 302 stwierdzonych gatunków). Badania Fizjograficzne nad Polską Zachodnią C, Poznań, 38: 5-21.

DZIABASZEWSKI A. 1991. Pająki grądowego rezerwatu „Jakubowo" ze szczególnym uwzględnieniem fenologii oraz struktury zgrupowań Aranei. Prace komisji biologicznej, PTPN, Poznań, 73: 35-57.

FEI R.I. \& GAO J.C. 1996. One new record genus and two new record species of Erigoninae from China (Araneae: Linyphiidae: Erigoninae) (in Chinese, with English abstract). Journal of Norman Bethune University of Medical Sciences, Changchun, 22: 247-248.

FICKERT C. 1876. Verzeichniss der schlesischen Spinnen. Zeitschrift für Entomologie, Breslau (N. F.) 5: $46-76$.

GAJDOŠ P., SVATOŇ J. \& SLOBODA K. 1999. Catalogue of Slovakian spiders. Bratislava, 337 pp.

HAJDAMOWICZ I., STAŃSKA M. \& RUTKOWSKI T. 2014. Walckenaeria incisa (O.P.- CAMBRIDGE) - a rare European species, new to Poland (Araneae: Linyphiidae). Genus, 25 (3): 357-363.

JAŁOSZYŃSKI P. \& KONWERSKI SZ. 2001. Znaczenie parków śródmiejskich w zachowaniu różnorodności gatunkowej chrząszczy (Coleoptera) na przykładzie parku „Cytadela” w Poznaniu. In: INDYKIEWICZ P., BARCZAK T. \& KACZOROWSKI G. (eds), Bioróżnorodność i ekologia populacji zwierzęcych w środowiskach zurbanizowanych. Wydawnictwo NICE. Bydgoszcz, pp. 46-51.

Komposch C. \& NATMESSNIG I. 2001. Ein Massenauftreten der Zwergspinne Troxochrus nasutus in Kärnten. Carinthia II, 191: 497-516.

KrzyŻanowska E., Dziabaszewski A., Jackowska B., \& StaręGa W. 1981. Spiders (Arachnoidea, Aranei) of Warsaw and Mazovia. Memorabilia Zoologica, Warszawa, 34: 87-110.

KulCZYNSKI W. 1876. Dodatek do fauny pajęczaków Galicyi. Sprawozdania Komisyi Fizyograficznej, Kraków, 10: 41-67.

KULCZYŃSKI W. 1881. Wykaz pająków z Tatr, Babiej góry i Karpat szlązkich z uwzględnieniem pionowego rozsiedlenia pająków żyjących w Galicji zachodniej. Sprawozdania Komisyi Fizyograficznej, Kraków, 15: 1-75.

KuLCZYŃSKI W. 1882. Spinnen aus der Tatra und den Westlichen Beskiden. Kraków, 34 pp.

KulCZYŃSKI W. 1884. Conspectus Attoidarum Galiciae. Przegląd krytyczny pająków z rodziny Attoidae żyjących w Galicji. Rozprawy i Sprawozdania z Posiedzeń Wydziału Matematyczno-Przyrodniczego Akademii Umiejętności, Kraków, 12: 136-232.

KULCZYŃSKI W. 1890. Galicyjskie pająki z rodziny Salticoidae. Sprawozdanie Gimnazjum Św. Jacka, Kraków, 33 pp.

Kupryjanowicz J. 2005. Pająki (Araneae) Biebrzańskiego Parku Narodowego. In: DYRCZ A., \& WerPACHOWSKI C (eds). Przyroda Biebrzańskiego Parku Narodowego, pp. 275-299. Biebrzański PN, Osowiec-Twierdza, 440 pp.

KupRYjanowicz J. 2008. Pająki, Araneae. In: Bogdanowicz W., Chudzicka E., PILIPIUK I. \& SkiBIŃSKA E. (eds), Fauna of Poland. Characteristics and checklist of species. Vol. 3, pp. 223-239. Museum and Institute of Zoology, PAS, Warszawa, 604 pp.

LE PERU B. 2011. The spiders of Europe, a synthesis of data: Volume 1 Atypidae to Theridiidae. Mémoires de la Société Linnéenne de Lyon, 2: 1-522.

LEBERT H. 1875. Verzeichnis Schlesischer Spinnen mit Aufzählung der schlesischen Myriapoden, Tübingen, 63 pp.

Logunov D.V. \& Kronestedt T. 2003. A review of the genus Talavera Peckham and Peckham, 1909 (Araneae, Salticidae). Journal of Natural History, 37: 1091-1154. 
ŁĘGOWSKI D. 2001. Waloryzacja Puszczy Białowieskiej metodą zooindykacyjną na podstawie pająków (Aranei). In: SzujecKi A. (ed.) Próba szacunkowej waloryzacji lasów Puszczy Białowieskiej metodą zooindykacyjną pp. 207233. SGGW Warszawa, 412 pp.

Menge A. 1868. Preussische Spinnen. II. Abtheilung. Schriften der Naturforschenden Gesellschaft in Danzig (N. F.), 2: 153-218.

Menge A. 1873. Preussische Spinnen. VI. Abtheilung. Schriften der Naturforschenden Gesellschaft in Danzig (N. F.), 3: 327-374.

MIKULSKA I. 1950. Materiały do poznania pająków jako elementu składowego biocenozy kilku lasów Karpat Śląskich. Wydawnictwo śląskie. Prace Biologiczne, PAU Kraków, 2: 111-140.

NenTwig W., Blick T., GloOR D., HÄNGGI A. \& KROPF C. 2017. Spiders of Europe. www.araneae.unibe.ch. Version 04.2017, accessed on: 1.05.2017.

OtTo S. \& FloREN A. 2007. The spider fauna (Araneae) of tree canopies in the Białowieża Forest. Fragmenta Faunistica, 50 (1): 57-70.

Pax F. 1936. Die Reyersdorfer Tropfsteinhöhle und ihre Tierbevölkerung. Mitteilungen über Höhlen- und Karstforschung: 97-122.

Petrusewicz K. 1937. Katalog der echten Spinnen (Araneae) Polens. Festschrift zum 60. Geburstage von Professor Dr. Embrik Strand 3: 140-216.

PILAWSKI S. 1963. Pająki nowe dla fauny Dolnego Śląska. Przegląd Zoologiczny 7: 43-52.

PILAWSKI S. 1967. Materiały do znajomości pająków (Araneae) Wzgórz Trzebnickich. Przegląd Zoologiczny 11: 391-404.

PRÓSZYŃSKi J. \& STARĘGA W. 1971. Pająki - Aranei. Katalog fauny Polski, 33. PWN, 382 pp.

PRÓSZYŃSKi J. \& STARĘGA W. 1997. Araneae. In: Razowski J. (ed.), Wykaz zwierząt Polski. Vol. 4: $173-199$. Wydawnictwo ISEZ PAN, Kraków, 304 pp.

REIMOSER E. 1937. Spinnentiere oder Arachnoidea. VIII. Gnaphosidae oder Plattbauchspinnen. Anyphaenidae oder Zartspinnen. Clubionidae oder Röhrenspinnen. Die Tierwelt Deutschlands. Jena, 33: 1-99.

RoBERTS M.J. 1987. The spiders of Great Britain and Ireland, Volume 2: Linyphiidae and check list. Harley Books, Colchester, England, 204 pp.

RoBerTs M.J. 1995. Spiders of Britain \& Northern Europe. Collins Field Guide, Harper Collins, London, 383 pp.

RozwaŁKA R. 2004. Materiały do znajomości pająków (Araneae) Roztocza. Nowy Pamiętnik Fizjograficzny, Warszawa, 3 (1-2): 101-116.

RozWAlKA R. 2008. Pocadicnemis carpatica (CHYZER, 1894) (Araneae: Linyphiidae) - a new species of spider to the fauna of Poland. Annales UMCS, sec. C., 63: 129-132.

RozwaŁKa R. 2010a. Materiały do znajomości pająków Araneae Bieszczadów i Bieszczadzkiego Parku Narodowego. Roczniki Bieszczadzkie 18: 167-177.

RoZWAŁKA R. 2010b. Zbiór pająków (Araneae) Muzeum Górnośląskiego w Bytomiu. Acta entomologica silesiana 18: 79-94.

RozWAŁKA R. 2012. Materiały do znajomości pająków Araneae Bieszczadzkiego Parku Narodowego. Roczniki Bieszczadzkie 20: 156-195.

RozwaŁKa R. 2014. Materiały do znajomości pająków Araneae Beskidu Wschodniego. Roczniki Bieszczadzkie 22: 239-350.

ROZWALKA R. \& BIELAK-BIELECKI P. 2008. Wstępna charakterystyka pająków korowych parków śródmiejskich Lublina i Świdnika w okresie zimowym. In: INDYKIEWICZ P., JERZAK L. \& BARCZYK T. (eds), Fauna miast. Ochronić różnorodność biotyczną w miastach, pp. 290-296. Wydawnictwo Pomorze, Bydgoszcz, 634 pp.

RozWAŁKa R., RutKowSKi T. \& BIELAK-BIELECKI P. 2013. New data on introduced and rare synanthropic spiders (Arachnida: Araneae) in Poland. Annales UMCS, Sec. C, 68 (1): 127-150.

ROZWAŁKA R. \& STAŃSKA M. 2008. Lista gatunków pająków (Araneae) Polski. Available at: http://www.arachnologia.edu.pl/gatunki/7-pajaki-polski.html

SAARISTO M.I. 1971. Revision of the genus Maro O.P.-Cambridge (Araneae, Linyphiidae). Annales Zoologici Fennici 8: 463-482.

SNAZELl R. 1978. Pseudomaro aenigmaticus Denis, a spider new to Britain (Araneae: Linyphiidae). Bulletin of the British Arachnological Society 4: 251-253.

STAŃSKA M. 2007. Rare and threatened spider species (Araneae) in selected types of deciduous forests in the Białowieża Forest. Nature Conservation 64: 13-29.

STAŃSKA M. \& ŁYDKOWSKA M. 2008. Pająki (Araneae) dąbrowy świetlistej w rezerwacie Dębniak. Leśne Prace Badawcze 69 (4): 309-320.

StARĘGA W. 1971. Pająki (Aranei) Bieszczadów. Fragmenta Faunistica 17: 53-126.

STARĘGA W. 1972. Nowe dla fauny Polski i rzadsze gatunki pająków (Aranei), z opisem Lepthyphantes milleri sp. n. Fragmenta Faunistica 18: 55-98.

StARĘGA W. 1974. Materiały do znajomości rozmieszczenia pająków (Aranei) w Polsce. Fragmenta Faunistica 19: 395-420.

STARĘGA W. 1976. Pająki (Aranei) Pienin. Fragmenta Faunistica 21: 233-330. 
StARĘGA W. 1978. Materiały do znajomości rozmieszczenia pająków (Aranei) w Polsce, III-VII. Fragmenta Faunistica 23: 259-302.

StARĘGA W. 1983. Wykaz krytyczny pająków (Aranei) Polski. Fragmenta Faunistica 27: 149-268.

STARĘGA W. 1984. Materiały do znajomości rozmieszczenia pająków (Aranei) w Polsce, VIII-X. Fragmenta Faunistica, 28: 79-136.

STARĘGA W. 1988. Pająki (Aranei) Gór Świętokrzyskich. Fragmenta Faunistica 31: 185-359.

STARĘGA W. 1996a. Spinnen (Araneae) aus der Borkenheide und anderen Lokalitäten der Masurischen Seenplatte. Fragmenta Faunistica, 39: 287-311.

StARĘGA W. 1996b. Spinnen (Araneae) von oberschlesischen Abraumhalden des Steinkohlebergbaus. Fragmenta Faunistica, 39: 329-344.

StAREgA W. 2000. Spinnen aus Roztocze und anliegenden Gebieten. Fragmenta Faunistica 43: 59-89.

StARĘGA W. 2001. Pająki (Araneae) Bieszczadzkiego Parku Narodowego. Monografie Bieszczadzkie, Ustrzyki Dolne, 7: 55-66.

StaręGa W. 2003. Pająki (Araneae) Puszczy Knyszyńskiej. Nowy Pamiętnik Fizjograficzny, Warszawa, 1: 95-206.

StARĘGA W. \& KuprYJANOWICZ J. 2001. Araneae - pająki. In: GuTOWSKI J. \& JAROSZEWICZ B. (eds), Katalog fauny Puszczy Białowieskiej, pp. 55-63. IBL, Warszawa, 404 pp.

STARĘGA W. \& NAKAZIUK G. 1987. Pająki (Aranei) z okolic Międzyrzeca Podlaskiego oraz uzupełnienia i sprostowania wiadomości o pająkach Podlasia. Rocznik Międzyrzecki, Międzyrzec Podlaski, 16-17: 232-245.

StAudT A., WeBER D. \&NÄHRIG D. 2012 Webspinnen (Arachnida, Araneae) aus Höhlen des Grossherzogtums Luxemburgs. Ferrantia, 69: 115-157.

STERZYŃSKA M. \& ŚLEPOWROŃSKI A. 1994. Spiders (Aranei) of tree canopies in Polish pine forests. Fragmenta Faunistica 36: 485-500.

SZYMKOWIAK P. 1993. Pająki (Aranei) rezerwatu przyrody „Mielno”. Parki Narodowe i Rezerwaty Przyrody 12 (4): 59-76.

TACZANOWSKI W. 1866. Spis pająków zebranych w okolicach Warszawy w ciągu roku 1865. Wykaz Szkoły Głównej Warszawskiej, Warszawa, 5: 1-14.

THALER K. 1991. Über wenig bekannte Zwergspinnen aus den Alpen-VIII (Arachnida: Aranei, Linyphiidae: Erigoninae). Revue suisse de zoologie, 98: 165-184.

Thaler K. \& Plachter H. 1983. Spinnen aus Höhlen der Fränkischen Alb, Deutschland (Arachnida: Araneae: Erigonidae, Linyphiidae). Senckerbergiana Biologica, 63: 249-263.

WiŚNIEWSKI K., ROZWAŁKA R. \& WESOŁOWSKA W. 2013. The first record of Hahnia difficilis Harm, 1966 (Araneae, Hahniidae) in Poland. Fragmenta faunistica, 56 (1): 55-63.

WIŚNIEWSKI K. \& WESOŁOWSKA W. 2015. Maro lehtineni (Araneae: Linyphiidae) - a spider species new to the fauna of Poland. Arachnologische Mitteilungen, 50: 81-84.

Woźny M., CzajKa M., Pilawski S. \& Bednarz S. 1988. Pająki (Aranei) polskich Sudetów, Acta Universitatis Wratislaviensis, 972, Prace Zoologiczne 19: 53-130.

World Spider Catalog (WSC) 2017. Natural History Museum Bern, online at http://wsc.nmbe.ch, version 18.0, accessed on 10.06.2017.

ŻABKA M. 1997. Salticidae - Pająki skaczące (Arachnida: Araneae). Fauna Polski. 19. Warszawa, Muzeum i Instytut Zoologii PAN, 189 pp.

\section{STRESZCZENIE}

\section{[Nowe stanowiska z południowowschodniej Polski kilku rzadkich gatunków pająków (Araneae)]}

Z południowo-wschodniej Polski podano nowe stanowiska rzadkich gatunków pająków: Anelosimus vittatus, Clubiona corticalis, Nusoncus nasutus, Pocadicnemis carpatica, Pseudicius encarpatus, Pseudomaro aenigmaticus i Talavera thorelli. Zebrane dane uzupełniają informacje o rozmieszczeniu i preferencjach siedliskowych tych gatunków na terenie kraju. Na podstawie analizy piśmiennictwa ustalono również, że występowanie w Polsce Anelosimus pulchellus jest bardzo wątpliwe i prawdopodobnie wszystkie informacje o tym gatunku odnoszą się do A. vittatus. Skorygowano dane innych autorów o występowaniu Clubiona corticalis jak również o Pseudicius encarpatus. Przedstawiono również argumenty wskazujące, że Pseudomaro aenigmaticus jest gatunkiem europejskim, a informacje o jego występowaniu w Chinach należy uznać za błędne. 